\title{
Leonardo DaVinci's contributions to medical physics and biomedical engineering: celebrating the life of a 'Polymath'
}

\author{
Tomas Kron $^{1,2,3} \cdot$ Prem Krishnan ${ }^{1}$
}

Published online: 2 May 2019

๑ Australasian College of Physical Scientists and Engineers in Medicine 2019

May 2, 2019 marks the 500th anniversary of Leonardo da Vinci's death. This presents an opportunity to reflect on his contributions to Medical Physics and Biomedical Engineering and consider how individuals and their work are related to the time they live and how they can sometimes transcend it.

The renaissance has been an important time in western history between around 1350 and 1600 when art, architecture and science changed dramatically. It is associated with several important political developments such as the development of banking, Protestantism, stronger cities and the fall of the Byzantine empire (1453) as well as important discoveries (America) for the Western world, and inventions such as the mechanical clock and printing with moveable letters. Also gunpowder-with all its impact—-became first known in Europe in the early renaissance.

Printing and the standardization of written languages through the work of people like the Italian poet Dante, and German cleric Martin Luther, made literacy and education more accessible to a broader population. This in turn facilitated an appreciation of knowledge, arts, discovery and education as values in themselves. Going hand in hand was a rediscovery of Greek and Roman art and philosophy, which introduced a cultural counterbalance to the dominance of the church that had been the foundation of developments in Europe throughout the medieval ages.

There are many publications discussing the emergence of art as a powerful societal factor in the renaissance and also the role individuals have played in it. Giorgio Vasari's

Tomas Kron

Tomas.Kron@petermac.org

1 Department of Physical Sciences, Peter MacCallum Cancer Centre, 305 Grattan Street, Melbourne, VIC 3000, Australia

2 Sir Peter MacCallum Institute of Oncology, University of Melbourne, Parkville, Australia

3 Centre for Medical Radiation Physics, University of Wollongong, Wollongong, Australia book, "The Lives of the Most Excellent Painters, Sculptors, and Architects" is one of the most important sources for the visual arts [1]. Published in 1550 it soon became the reference book for art history. It includes a chapter on Leonardo da Vinci whom Vasari describes in the following way:

"... there was an infinite grace in all his actions; and so great was his genius, and such its growth, that to whatever difficulties he turned his mind, he solved them with ease" (p. 227) [1].

Leonardo da Vinci is often described as a 'polymath', someone who has "learned much" (from Greek polymathes). The emphasis here is usually on "learned much in different fields of study' and Leonardo certainly excelled in many subjects ranging from drawing, painting and music, to sculpture and architecture, and of course to science and engineering.

\section{Leonardo di ser Piero da Vinci: a brief biography}

Leonardo da Vinci was born out of wedlock on April 15, 1452 close to the village of Vinci in Tuscany near Florence. His father Piero da Vinci was an educated man from a family of notaries and his mother Caterina very likely a peasant. It appears that his abilities were noticed early and he commenced an apprenticeship with Andrea del Verrocchio in Florence at the age of 14. Andrea del Verrochio was a wellknown painter, sculptor and gold smith. Leonardo lived and worked in his household for seven years, and according to Vasari, met many other important artists like Perugino and Ghirlandaio there. Already in that time Leonardo devoted time to drawing architectural and scientific matter.

In 1482 Leonardo went to Milan to serve Ludovico Sforza who became ruler of Milan in 1494. In his application letter, Leonardo highlighted his abilities as a war engineer (he knew that this was what Ludovico was after) but ending with "Likewise in painting, I can do everything possible as well as 
any other, whosoever he may be" [2]. Not very modest but nevertheless true given that he painted Lady with an Ermine (1489/90; National Museum in Krakow) and The Last Supper (1495-98; Convent of Santa Maria delle Grazie in Milan) in this time. In the first years of the sixteenth century Leonardo spend time in several Italian cities (Venice, Florence, Milan and Rome). In this time also the Leicester Codex (compiled 1506-1513) was compiled. It is a rich source of information about Leonardo, which was bought in 1994 by Bill Gates for US\$ $30 \mathrm{M}$ from the millionaire Hammer and made publically available (https://hammercodex.com/home). Leonardo da Vinci moved to Rome in 1513 to work in the Vatican and finally moved to France to serve king Francois I of France in Amboise at the river Loire. It is here he died, 67 years of age, of a stroke on May 2, 1519. According to his will 60 beggars followed his coffin.

Leonardo must have been a rather unusual man for hisand probably also our-time. He was good looking, but never married and it is not recorded that he had a partner at any time. He was described as a great orator and always accommodating and friendly towards his compatriots [3]. Apparently, he also enjoyed the finer things of life and liked to dress well as can be seen in the paintings and drawings that show him. Based on the position of the pupil of the eyes in these paintings it has recently been debated if Leonardo had strabismus (eyes do not properly align when looking at an object) [4]. This may even have contributed to his ability to appreciate spatial dimensions and transfer them into a two dimensional representation. On the other hand, the assumption that he may have been dyslexic (https://www.dyslexia.com/famous/leonardo-da-vinci/) is not likely to be correct [5]. His custom to write often from right to left more likely reflects his ambidexterity or an attempt to conceal some of the meaning of the text to a quick on-looker [6].

Leonardo was not known for working fast [3]. He worked for four years on the Mona Lisa [1] and many of his works are unfinished. As Vasari puts it:

"...he would have made great proficience, if he had not been so variable and unstable, for he set himself to learn many things, and then, after having begun them, abandoned them" (p. 229) [1]

Leonardo was full of appreciation for nature; a rationale for him to be vegetarian, which would have been rather unusual for his time (unless poverty was the reason). He believed that "people and animals were inextricably entwined and interdependent on each other for survival" [7] and reportedly bought caged birds at the markets and let them free.

\section{Leonardo and biomedical engineering}

One only needs to look at the drawing of the 'Vitruvian Man' (around 1490, Galleria dell' Accademia, Venice, Italy), one of the most recognizable drawings in the world, to appreciate the link to biomedical engineering. Vitruvius was a Roman architect and engineer who worked on proportions in buildings and humans. Leonardo put this into one stunning drawing.

Leonardo da Vinci was the first engineer who tried to understand everything that happened around him. This understanding ranges from nature that surrounded him to the machines that were used during the renaissance period. He would then utilize this knowledge to develop new machines. He wrote down most of his inventions using mercantile script (Mirror writing) [8]. His journal contains words and drawing that describe all aspects of his design with the most important one summed in the Codex Leicester, the before mentioned collection of scientific writings edited by Leonardo da Vinci himself.

Leonardo made many contributions to physiology, often inspired by his artistic interests: music related to the studies of the trachea [9] and visual arts to ocular optics [10]. Leonardo investigated blood flow, muscles and physiology of breathing. This lead to one of the intriguing inventions which Leonardo da Vinci designed while working in Venice for covert attacks on enemy ships in 1500: Scuba Gear (https://www.da-vinci-inventions.com/scuba-gear.aspx). It included a leather diving suit with a bag like mask that went over the diver's head. Cane tubes were attached to the diver's nose through the mask which connects to a diving bell that floats on the surface. The mask also had a valve operated balloon which could be inflated to deflate, aiding the diver to easily sink or surface. This setup for its time would have worked brilliantly if it was put to practice. However, this idea (like many others) was only made famous after the Codex Atlanticus was published after Loenardo's death. Nowadays scuba divers use a pressurized cylinder and a regulator to submerge, which is similar to the principle behind anesthetic machines, a stable in the biomedical engineering world. We have high pressure supply lines, which are regulated and mixed before inducing a patient to make them unconscious. In all these cases-like in Leonardo's invention-air is controlled so it can be delivered in a desired state.

\section{Leonardo and medical physics}

Several sources refer to Leonardo as the first 'medical physicist' based on his detailed understanding of the human body, illustrated in drawings and sketches [11, 12]. 
Others credit Santorio Santorio a Venetian physician living about 100 years later with being the first person to systematically apply physics measurements to medicine [13]. However, Leonardo's studies and works extend beyond a description of physiology and look for insights and understanding by building models, all traits that generally characterize medical physicists. In any case there is no doubt that Leonardo's works highlight also the close relation that medical physics enjoys to biomedical engineering.

Having started his training and career as an artist, he later in life drifted more towards 'scientific' observation and experimentation. This principle was even applied to love:»Nessuna cosa si può amare nè odiare, se prima non si ha cognizione di quella." [3] (There is nothing one can love or hate that one does not fully understand). Sigmund Freud who attributes this phrase to Leonardo thought that this was strange at best... [3]. Vasari intimates that Leonardo regretted his focus on research and science on his deathbed as it had not allowed him to put more effort in the arts to please God (p. 242) [1]. True or not it highlights that even a man of the faculties of Leonardo may not have been able to complete everything in life of which he was capable.

Leonardo's largest contributions to physics and medical physics are probably in the field of optics. That is not surprising given the significance of optics for creation and perception of art as well as for scientific exploration [10]. While Leonardo's writings on optics are used primarily in connection with his art [14] including the authentication of Salvator Mundi, [15], for scientists his methodological approach is most interesting. Building on theories of Plato and Aristotle, he studied the eye in his usual meticulous experimental manner:

“... in order to see the inside (of the eye) well without spilling its humour, you should place the complete eye in white of egg and boil it until it becomes solid, cutting the egg and the eye transversely so no part of the middle portion is poured out." [10]

This experimental approach coupled with Leonardo's ability to capture the results in drawings and writings are highly relevant for today's medical physicists as he managed to base his studies on the literature (in the case of optics unfortunately not always correct), obtain new insights through very clever experimental studies and document all this in a way that could reach others.

\section{Conclusion}

Leonardo was an exceptional person whose ideas inspired his contemporaries as much as us 500 years later. His paintings include the most recognizable piece of art in the world (Mona Lisa, The Louvre, Paris) and the one that fetched the highest price at auction ever (Salvator Mundi, \$US $450 \mathrm{M}$ or about three proton treatment facilities). However, his contributions to and inspiration for physical scientists and engineers are priceless.

\section{References}

1. Vasari G (2006) The lives of the most excellent painters, sculptors, and architects. The Modern Library, New York

2. The skills of Leonardo Da Vinci. In: Usher S (ed) Letters of note, vol 2019. https://www.lettersofnote.com/2012/03/skills-of-davinci.html

3. Freud S (1910) Eine Kindheitserinnerung des Leonardo da Vinci. S. Fischer Verlag, Frankfurt/M

4. Tyler CW (2019) Evidence that Leonardo da Vinci had strabismus. JAMA Ophthalmol 137:82-86

5. Mangione S (2019). Was Leonardo Da Vinci Dyslexic? Am J Med

6. McManus IC, Drury H (2004) The handedness of Leonardo da Vinci: a tale of the complexities of lateralisation. Brain Cogn $55: 262-268$

7. The L (2019) Leonardo's unity. Lancet 393:1386

8. Sniderman D (2012) Leonardo Da Vinci. American Society of Mechanical Engineers. https://www.asme.org/engineering-topic s/articles/history-of-mechanical-engineering/leonardo-da-vinci.

9. West JB (2017) Leonardo da Vinci: engineer, bioengineer, anatomist, and artist. Am J Physiol Lung Cell Mol Physiol 312:L392-L397

10. Keele KD (1955) Leonardo da Vinci on vision. Proc R Soc Med 48:384-390

11. Keevil SF (2012) Physics and medicine: a historical perspective. Lancet 379:1517-1524

12. Kostylev V (2000) Medical physics: yesterday, today, and tomorrow. Biomed Eng 34:106-112

13. Duck FA (2014) The origins of medical physics. Phys Med 30:397-402

14. Bitler N (2011) Leonardo da Vinci's study of light and optics: a synthesis of fields in The Last Supper. Intersect 4:26-34

15. Kemp M (2011) Sight and salvation. Nature 479:174-175

Publisher's Note Springer Nature remains neutral with regard to jurisdictional claims in published maps and institutional affiliations. 